\title{
Correction to: The use of remote sensing satellite using deep learning in emergency monitoring of high-level landslides disaster in Jinsha River
}

\author{
Leijin Long ${ }^{1} \cdot$ Feng $\mathrm{He}^{2} \cdot$ Hongjiang Liu ${ }^{3}$
}

Published online: 22 February 2022

○) Springer Science+Business Media, LLC, part of Springer Nature 2022

\section{Correction to: The Journal of Supercomputing (2021) 77:8728-8744 https://doi.org/10.1007/s11227-020-03604-4}

The article "The use of remote sensing satellite using deep learning in emergency monitoring of high-level landslides disaster in Jinsha River", written by Leijin Long, Feng He, Hongjiang Liu, was originally published online on the publisher's internet portal on 26 January 2021 with Open Access under a Creative Commons Attribution (CC BY) license 4.0.

After publication in volume 77, issue 8, page 8728-8744, the author(s) decided to cancel the Open Access. Therefore, the copyright of the article changed on 2 February 2022 to $\odot$ Springer Science + Business Media, LLC, part of Springer Nature 2021 with all rights reserved.

Publisher's Note Springer Nature remains neutral with regard to jurisdictional claims in published maps and institutional affiliations.

The original article can be found online at https://doi.org/10.1007/s11227-020-03604-4.

Feng He

hefeng@cau.edu.cn

1 Financial Department, Yunnan University of Finance and Economics, KunMing 650221, YunNan, China

2 School of Urban and Environmental Sciences, Yunnan University of Finance and Economics, KunMing 650221, YunNan, China

3 School of Tourism, LeShan Normal University, LeShan 614000, SiChuan, China 